\title{
Chapter 11 \\ Dry Matter Production as a Basis of Starch Production in Sago Palm
}

\author{
Yoshinori Yamamoto
}

\begin{abstract}
The differences of starch productivity of sago palms among folk varieties (hereafter, varieties) are discussed from the viewpoint of dry matter production which has been rarely reported in sago palm, to provide basic knowledge to establish the cultivation methods of sago palm and to select varieties for new introduction and breeding of new varieties. The research was performed in Kendari, Southeast Sulawesi, Indonesia, to clarify the dry matter production and the factors related to it in the sago palm varieties with different starch yields. The results revealed that the varietal differences of starch yield of sago palm varieties, Molat (425 kg dry starch/ palm) and Rotan (142 kg in dry starch/palm), are mainly based on the biomass difference and not on the difference of matter distribution ratios to the harvesting part (trunk/pith). The biomass production in sago palm is closely related to the leaf area per plant, mainly determined by the leaf area per leaf compared to the number of leaves per plant. The leaflet width contributed most to the leaf area per leaf. I concluded that the leaf area in sago palm was the key factor to determine the starch yield and varietal differences of leaflet width should be paid attention to as an important character to determine the leaf area.
\end{abstract}

\subsection{Introduction}

Sago palm is a clustering (soboliferous), perennial plant which accumulates large quantities of starch in the stem (trunk). This characteristic of sago palm gives it tolerance to various climatic conditions. It can grow in marginal land such as deep peat soil, high water table areas, etc. Besides the increase of production of major world starch crops, it is very important to evaluate and develop new starch crops to effectively meet the growing demand from the predicted population increase in this century. New starch sources can reduce hunger in the world and, moreover, help deal with the crop production problems brought about by climate change due to global warming.

Y. Yamamoto $(\square)$

Formerly, Faculty of Agriculture, Kochi University, Nankoku-shi, Kochi, Japan

e-mail: yamayosi@kochi-u.ac.jp 
The starch productivity of sago palm is affected by environmental conditions, cultivation and management methods, processing practices and harvesting stage, as well as variety (i.e., folk variety) (Yamamoto 2011). The amount of starch accumulated in the trunk varies greatly among regions and/or varieties (Yamamoto 2006, 2011). To precisely understand the regional and/or varietal differences of starch productivity among sago palms, it essentially needs to be researched from the viewpoint of dry matter production. However, limited research on dry matter production in sago palm has been done so far (Yatsugi 1977; Flach and Schuiling 1991; Kaneko et al. 1996; Yamamoto et al. 2014, 2016).

Starch yield of sago palm was analyzed according to biomass produced, biomass ratio of harvesting portion (pith), and the starch percentage in pith. Therefore, to calculate the starch yield, starch yield $($ dry starch $)=$ biomass $($ dry weight $) \times$ pith dry weight/biomass (dry weight) $\times$ starch dry weight/pith dry weight. That is, the starch yield is determined by biomass, biomass distribution ratio to pith, and starch content in pith. As for biomass production, it is mainly determined by leaf area, photosynthetic rate, and growth duration.

This chapter discussed the dry matter production and the factors related to it in sago palm to clarify the differences in starch productivities in sago palm varieties.

\subsection{Biomass Production and Related Factors in Sago Palm}

The main data described in this chapter were collected in Kendari, Southeast Sulawesi, Indonesia, from 1998 to 2000. In Kendari, measurements were made of the changes in total sugar and starch in the pith of three major varieties, with general and local names: Molat (Roe), Tuni (Runggunmanu), and Rotan (Rui), along with palm ages (Yamamoto et al. 2010). Based on the starch yield results, Molat and Rotan were chosen as the highest and lowest yielding varieties to compare the changes of each organ or part biomass weight of the shoot (aboveground part) and leaf area and leaf area-related characters. Thirteen Molat palms, 1-7 years after trunk formation (ATF), and nine Rotan palms, 1-7 years ATF, of different ages were sampled to determine their biomass and leaf area (Yamamoto et al. 2014, 2016).

\subsubsection{Leaf Area}

The sago palm leaf is pinnate and compound, consisting of rachis, petiole, and many leaflets attached to the rachis. The size of each leaf part increases from the lower to the higher node until the trunk formation stage. The size of each part almost reaches a maximum value at about the trunk formation stage, and the size remains the same until flower bud formation stage. However, the size gradually decreases acropetally after the flower bud formation stage (Yamamoto 1998). Nakamura et al. (2009) developed a method to analyze the leaf area of sago palm based on studies of leaf and leaflet characters (Nakamura et al. 2004, 2005). 
Leaf area per plant was compared between Molat and Rotan. The result showed a great difference in leaf area per plant between the two from the early stage after trunk formation. The leaf area of Molat increased linearly, but that of Rotan did not show a clear increase after trunk formation. Table 11.1 shows the leaf and leaflet characters (average values after trunk formation to harvesting) in both varieties. All of the values in the measured characters of leaf and leaflets were higher in Molat than in Rotan except specific leaf area (SLA), and the leaf areas per plant on the average after trunk formation and at harvesting stage were 2.0 and 2.9 times higher in Molat $\left(269.5\right.$ and $\left.439.0 \mathrm{~m}^{2}\right)$ than in Rotan $\left(139.1\right.$ and $\left.150.0 \mathrm{~m}^{2}\right)$, respectively. The difference in leaf area per plant was mainly caused by the difference in leaf area per leaf (Molat 17.5, Rotan $11.1 \mathrm{~m}^{2}$ ) compared with that in the number of leaves per plant (Molat 15.0, Rotan 12.5). The differences of leaf area per leaf by the regions and/or varieties were reported by Flach and Schuiling (1991). As for the leaflet characters which related to the leaf area per leaf, the difference in leaflet width (Molat 11.6, Rotan $8.7 \mathrm{~cm}$ ) was the greatest, and it showed the closest relationship with the leaf area per leaf. Yamamoto (2016) reported the same relationships among the characters related to leaf and leaflet areas in the sago palm varieties around Lake Sentani near Jayapura, Papua, Indonesia.

\subsubsection{Photosynthesis}

Sago palm is classified as $\mathrm{C}_{3}$ plant based on its leaflet anatomy (Nitta et al. 2005) and characteristics of photosynthesis (Uchida et al. 1990). Although the research on photosynthesis of sago palm is minimal, Flach (1977) and Uchida et al. (1990) reported that the maximum photosynthetic rate is $13-15 \mathrm{mg} \mathrm{CO}_{2} / \mathrm{dm}^{2} / \mathrm{h}$ and $8-12 \mathrm{mg}$ $\mathrm{CO}_{2} / \mathrm{dm}^{2} / \mathrm{h}$, respectively, by using young seedlings grown in pots. Moreover, Uchida et al. (1990) clarified that a sago palm leaf attained a maximum photosynthetic rate after 37-45 days of unfolding of the leaf and more than $50 \%$ of the maximum photosynthetic rate was maintained for 70 days after the unfolding of the leaf. This implies the lateness of sago palm leaf to attain the maximum photosynthetic rate and to retard the photosynthetic rate compared to an annual plant (Uchida et al. 1990). Sago palm leaf shows the shade leaf characteristics because of the low light saturation point $\left(5.3 \mu \mathrm{mol} / \mathrm{m}^{2} / \mathrm{s}\right)$ (Uchida et al. 1990).

On the other hand, the photosynthetic rate of sago palm leaf after trunk formation growing in the field is higher than that of seedlings grown in pots, ranging from 25 to $27 \mathrm{mg} \mathrm{CO} / \mathrm{dm}^{2} / \mathrm{h}$ (Miyazaki et al. 2007). The photosynthetic rate differences between seedling and plant after trunk formation might be brought about by the differences in leaflet thickness, chlorophyll content, stomata density, etc. (Miyazaki et al. 2007). Leaf thickness and chlorophyll content (SPAD value) increase from sucker transplanting or emergence to trunk formation stage (Yamamoto et al. 2006). Uchida et al. (1990) reported that the photosynthetic rate of sago palm seedling is strongly affected by the stomata density. Omori et al. (2000) clarified that the differences in stomatal density based on the position in leaflets and leaves changed with palm age, that is, it ranged from ca. $50 / \mathrm{mm}^{2}$ on the adaxial side and ca. $400 / \mathrm{mm}^{2}$ on 


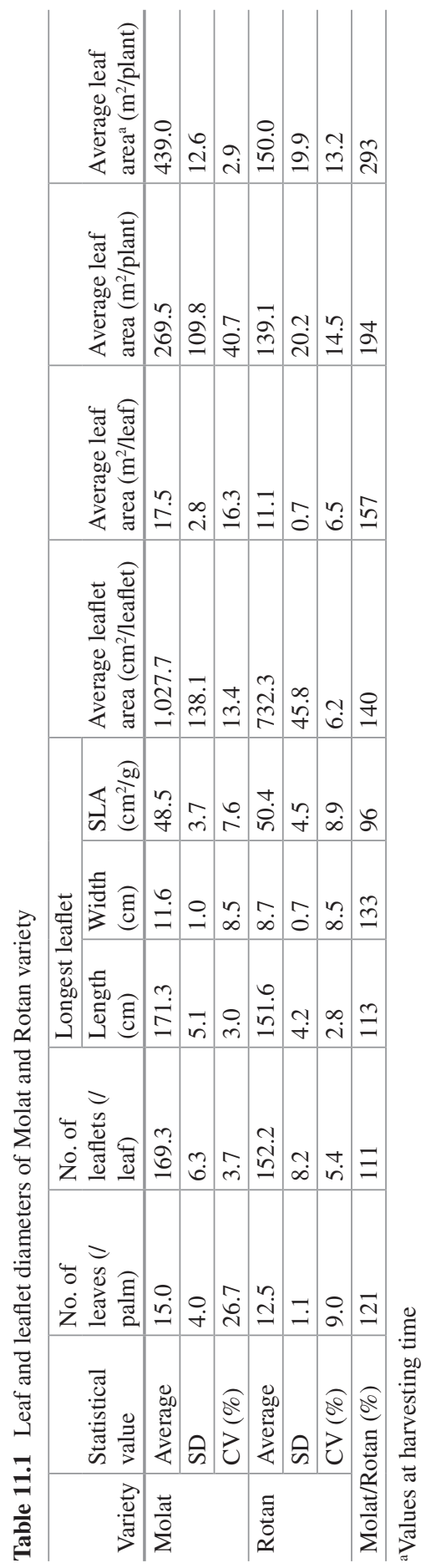


the abaxial side in the seedling stage to ca. $120 / \mathrm{mm}^{2}$ and ca. $1000 / \mathrm{mm}^{2}$ after trunk formation stage, respectively.

Miyazaki et al. (2007) reported the differences of photosynthetic rate of sago palm varieties growing in Bogor, Kendari, and Jayapura (around Lake Sentani), but the differences were small. According to Miyazaki et al. (2007) and the reports of the small differences in stomatal density by Omori et al. (1999), along with the study of mineral element contents in leaflets (Yoshida et al. 2000), there may be a small difference in photosynthetic rates between the Molat and Rotan varieties.

\subsubsection{Growth Duration}

The growth duration from sucker planting or emergence to flowering stage, that is, harvesting stage, varies greatly among varieties (Yamamoto 2011). The range of growth duration is from about 10 to 25 years (Yamamoto 1998, 2011). Moreover, the growth duration is affected by the soil types and soil nutrient conditions where the sago palms grow (Yamamoto 1998). The biomass of sago palm at harvesting stage is greatly influenced by the growth duration. Biomass production of early maturing varieties is lower than that of the late maturity varieties. Yamamoto (2011) reported that the difference in starch productivity was assumed to relate closely to the years to flowering, as reflected from the positive high correlation between the numbers of leaf scars and living leaves and the dry pith weight or starch yield.

The growth duration from trunk formation to harvesting was a little longer in Molat (7 years ATF) than in Rotan (5.5-7 years ATF); however, it was not very different (Table 11.2).

\subsubsection{Biomass}

The shoot fresh and dry weights ranged from 600 to $3053 \mathrm{~kg}$ in Molat and from 479 to $1123 \mathrm{~kg}$ in Rotan for the fresh weight and from 104 to $1028 \mathrm{~kg}$ in Molat and from 86 to $425 \mathrm{~kg}$ in Rotan for the dry weight (Table 11.2) and increased exponentially with years ATF. The annual weight gains ATF were $357.8 \mathrm{~kg} / \mathrm{year}$ in Molat and $92.5 \mathrm{~kg} /$ year in Rotan for the fresh weight and $144.3 \mathrm{~kg} / \mathrm{year}$ in Molat and $46.5 \mathrm{~kg} /$ year in Rotan for the dry weight, with 3.9 and 3.1 times higher values in Molat than in Rotan, respectively. The average shoot fresh and dry weights at the harvesting stage (three palms at 7 years ATF for Molat and three palms at 5.5-7 years ATF for Rotan) were 2781 and $986 \mathrm{~kg}$ for Molat and 1000 and $359 \mathrm{~kg}$ for Rotan.

The leaf dry weight of Molat ranged from 76 to $291 \mathrm{~kg}$ and increased exponentially with years ATF, while that of Rotan ranged from 62 to $107 \mathrm{~kg}$; a significant change with years ATF was not observed (Table 11.2). The trunk dry weight in both varieties ranged from 29 to $746 \mathrm{~kg}$ in Molat and from 25 to $336 \mathrm{~kg}$ in Rotan and increased exponentially with years ATF. The average trunk dry weight at harvesting stage in Molat (721 kg) was 2.7 times higher than that in Rotan (267 kg) (Table 11.2). 
Table 11.2 Changes in dry weight of each part of shoot of sago palm varieties after trunk formation in Kendari, Southeast Sulawesi, Indonesia

\begin{tabular}{|c|c|c|c|c|c|c|c|c|c|}
\hline \multirow[b]{2}{*}{ Variety } & \multirow[b]{2}{*}{$\begin{array}{l}\text { Years } \\
\text { ATF }^{a}\end{array}$} & \multicolumn{4}{|c|}{ Leaf (kg/palm) } & \multicolumn{3}{|c|}{ Trunk (kg/palm) } & \multirow[b]{2}{*}{$\begin{array}{l}\text { Shoot }(\mathrm{kg} / \\
\text { palm) }\end{array}$} \\
\hline & & Leaflet & Rachis & $\begin{array}{l}\mathrm{P}+ \\
\mathrm{LS}^{\mathrm{b}}\end{array}$ & Total & Bark & Pith & Total & \\
\hline \multirow[t]{14}{*}{ Molat } & 1 & 23.8 & 22.0 & 30.2 & 76.0 & 10.6 & 17.9 & 28.5 & 104.4 \\
\hline & 1 & 34.7 & 28.9 & 41.4 & 104.9 & 11.6 & 22.9 & 34.4 & 139.4 \\
\hline & 1 & 28.8 & 22.5 & 32.2 & 83.5 & 13.0 & 18.1 & 31.1 & 114.6 \\
\hline & 2 & 52.5 & 38.2 & 46.9 & 137.5 & 31.0 & 41.7 & 72.6 & 210.1 \\
\hline & 3.5 & 47.2 & 37.3 & 50.1 & 134.6 & 34.5 & 64.2 & 98.7 & 233.3 \\
\hline & 3.5 & 43.6 & 32.5 & 39.9 & 115.9 & 36.3 & 63.3 & 99.6 & 215.5 \\
\hline & 4 & 46.8 & 40.1 & 46.9 & 133.8 & 36.8 & 62.4 & 99.2 & 233.0 \\
\hline & 4 & 58.1 & 41.3 & 52.3 & 151.7 & 63.9 & 66.2 & 130.1 & 281.9 \\
\hline & 5 & 42.8 & 30.9 & 41.6 & 115.4 & 69.3 & 211.5 & 280.8 & 396.2 \\
\hline & 5.5 & 94.9 & 71.0 & 101.8 & 267.7 & 122.2 & 328.0 & 450.2 & 717.9 \\
\hline & 7 & 106.6 & 76.7 & 107.4 & 290.7 & 153.2 & 584.2 & 737.4 & 1028.1 \\
\hline & 7 & 101.8 & 69.0 & 90.8 & 261.6 & 123.1 & 558.2 & 681.2 & 942.8 \\
\hline & 7 & 97.4 & 57.7 & 84.8 & 239.9 & 145.7 & 600.0 & 745.6 & 985.5 \\
\hline & Aveg. & 101.9 & 67.8 & 94.3 & 264.1 & 140.6 & 580.8 & 721.4 & 985.5 \\
\hline \multirow[t]{10}{*}{ Rotan } & 1 & 22.6 & 14.6 & 24.6 & 61.8 & 6.7 & 17.9 & 24.6 & 86.4 \\
\hline & 1 & 31.7 & 19.6 & 29.5 & 80.8 & 13.6 & 23.1 & 36.7 & 117.6 \\
\hline & 1 & 26.4 & 16.1 & 29.0 & 71.5 & 14.0 & 18.6 & 32.6 & 104.1 \\
\hline & 3.5 & 21.7 & 15.3 & 20.9 & 57.9 & 25.8 & 44.7 & 70.6 & 128.5 \\
\hline & 3.5 & 34.3 & 24.0 & 33.0 & 91.3 & 37.4 & 82.5 & 119.9 & 211.2 \\
\hline & 4 & 22.1 & 16.5 & 23.2 & 61.7 & 27.8 & 44.7 & 72.5 & 134.2 \\
\hline & 5.5 & 30.1 & 21.4 & 27.4 & 78.9 & 43.1 & 151.9 & 195.0 & 273.9 \\
\hline & 6.5 & 40.3 & 29.2 & 37.7 & 107.2 & 55.9 & 215.7 & 271.6 & 378.8 \\
\hline & 7 & 32.4 & 26.0 & 30.8 & 89.2 & 65.3 & 270.3 & 335.5 & 424.7 \\
\hline & Avg. & 34.2 & 25.5 & 32.0 & 91.7 & 54.8 & 212.6 & 267.4 & 359.1 \\
\hline
\end{tabular}

a'Years after trunk formation

bPetiole + leaf sheath. The palms shown in gray color are at harvesting stage

Source: Yamamoto et al. (2016)

All the leaf components, leaflet, rachis, and petiole + leaf sheath, in Molat increased exponentially in dry weight with years ATF (Table 11.2). On the other hand, in Rotan, although that of rachis increased linearly, few changes were observed in the dry weights of leaflet and petiole + leaf sheath with years ATF. Among the leaf components, the dry weight of leaflet, rachis, and petiole + leaf sheath ranged from 24 to 107, 22 to 77, and 30 to $107 \mathrm{~kg}$ in Molat, respectively, and 22 to 40, 15 to 29 , and 21 to $38 \mathrm{~kg}$ in Rotan, respectively, showing the higher dry weight in the order of petiole + leaf sheath $\fallingdotseq$ leaflet $>$ rachis in both varieties.

Exponential increases of the bark and pith dry weights with years ATF in Molat and Rotan were observed. The dry weights of bark and pith ranged from 11 to $153 \mathrm{~kg}$ and from 18 to $600 \mathrm{~kg}$ in Molat, respectively, and from 7 to $65 \mathrm{~kg}$ and 18 to $270 \mathrm{~kg}$ in Rotan, respectively, while showing a marked varietal difference after 
4 years of trunk formation. The average bark and pith dry weight values at the harvesting stage in Molat (141 and $581 \mathrm{~kg}$ ) were 2.6 and 2.7 times higher than that in Rotan (55 and $213 \mathrm{~kg}$ ), respectively (Table 11.2).

\subsection{Dry Matter Distribution Ratio to Each Part of Sago Palm}

Table 11.3 shows the dry weight ratio of each organ or part to the shoot weight of varieties Molat and Rotan based on the values in Table 11.2. In contrast to the dry weight differences of each organ or part between the two varieties, there were no

Table 11.3 Changes in dry weight percentage of each part of shoot of sago palm varieties after trunk formation in Kendari, Southeast Sulawesi, Indonesia

\begin{tabular}{|c|c|c|c|c|c|c|c|c|c|}
\hline \multirow[b]{2}{*}{ Variety } & \multirow{2}{*}{$\begin{array}{l}\text { Years } \\
\text { ATFF }^{a}\end{array}$} & \multicolumn{4}{|c|}{ Leaf $(\%)$} & \multicolumn{3}{|c|}{ Trunk (\%) } & \multirow[b]{2}{*}{ Shoot $(\%)$} \\
\hline & & Leaflet & Rachis & $\mathrm{P}+\mathrm{LS}^{\mathrm{b}}$ & Total & Bark & Pith & Total & \\
\hline \multirow[t]{14}{*}{ Molat } & 1 & 22.8 & 21.0 & 28.9 & 72.7 & 10.1 & 17.1 & 27.3 & 100.0 \\
\hline & 1 & 24.9 & 20.7 & 29.7 & 75.3 & 8.3 & 16.4 & 24.7 & 100.0 \\
\hline & 1 & 25.1 & 19.6 & 28.1 & 72.9 & 11.3 & 15.8 & 27.1 & 100.0 \\
\hline & 2 & 25.0 & 18.2 & 22.3 & 65.4 & 14.7 & 19.8 & 34.6 & 100.0 \\
\hline & 3.5 & 20.2 & 16.0 & 21.5 & 57.7 & 14.8 & 27.5 & 42.3 & 100.0 \\
\hline & 3.5 & 20.2 & 15.1 & 18.5 & 53.8 & 16.9 & 29.4 & 46.2 & 100.0 \\
\hline & 4 & 20.1 & 17.2 & 20.1 & 57.4 & 15.8 & 26.8 & 42.6 & 100.0 \\
\hline & 4 & 20.6 & 14.7 & 18.6 & 53.8 & 22.7 & 23.5 & 46.2 & 100.0 \\
\hline & 5 & 10.8 & 7.8 & 10.5 & 29.1 & 17.5 & 53.4 & 70.9 & 100.0 \\
\hline & 5.5 & 13.2 & 9.9 & 14.2 & 37.3 & 17.0 & 45.7 & 62.7 & 100.0 \\
\hline & 7 & 10.4 & 7.5 & 10.4 & 28.3 & 14.9 & 56.8 & 71.7 & 100.0 \\
\hline & 7 & 10.8 & 7.3 & 9.6 & 27.7 & 13.1 & 59.2 & 72.3 & 100.0 \\
\hline & 7 & 9.9 & 5.9 & 8.6 & 24.3 & 14.8 & 60.9 & 75.7 & 100.0 \\
\hline & Avg. & 10.3 & 6.9 & 9.6 & 26.8 & 14.2 & 59.0 & 73.2 & 100.0 \\
\hline \multirow[t]{10}{*}{ Rotan } & 1 & 26.2 & 16.9 & 28.5 & 71.5 & 7.8 & 20.7 & 28.5 & 100.0 \\
\hline & 1 & 27.0 & 16.7 & 25.1 & 68.7 & 11.6 & 19.6 & 31.3 & 100.0 \\
\hline & 1 & 25.3 & 15.5 & 27.8 & 68.7 & 13.5 & 17.9 & 31.3 & 100.0 \\
\hline & 3.5 & 16.9 & 11.9 & 16.3 & 45.1 & 20.1 & 34.8 & 54.9 & 100.0 \\
\hline & 3.5 & 16.2 & 11.4 & 15.6 & 43.2 & 17.7 & 39.1 & 56.8 & 100.0 \\
\hline & 4 & 16.4 & 12.3 & 17.3 & 46.0 & 20.7 & 33.3 & 54.0 & 100.0 \\
\hline & 5.5 & 11.0 & 7.8 & 10.0 & 28.8 & 15.7 & 55.5 & 71.2 & 100.0 \\
\hline & 6.5 & 10.6 & 7.7 & 10.0 & 28.3 & 14.8 & 56.9 & 71.7 & 100.0 \\
\hline & 7 & 7.4 & 6.0 & 7.0 & 20.4 & 14.9 & 61.8 & 76.8 & 100.0 \\
\hline & Avg. & 9.7 & 7.2 & 9.0 & 25.8 & 15.1 & 58.1 & 73.2 & 100.0 \\
\hline
\end{tabular}

${ }^{a}$ Years after trunk formation

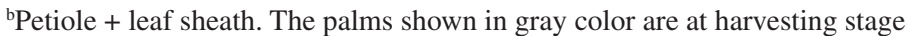

Source: Yamamoto et al. (2016) 
clear varietal differences in the changes of dry weight ratio of each organ or part to the shoot weight. The leaf and trunk weight ratio conversely changed showing 70-75 and $30-25 \%$ at trunk formation stage and 25-30 and 75-70\% at harvesting stage, respectively. The dry weight ratios were almost the same at 3-4 years after trunk formation; thereafter, the trunk ratio increased with years ATF, compared to the leaf ratio. These ratios at harvesting stage are similar to the results from sago palms growing in Sarawak, Malaysia (Flach and Schuiling 1991; Kaneko et al. 1996).

Moreover, the dry weight ratio of each part of leaf to the shoot dry weight decreased with years ATF. Petiole + leaf sheath dry weight decreased more rapidly than in the other two parts, due to the gradual shortening of the length with palm age (Yamamoto et al. 2014).

The dry weight ratio of bark in the trunk to the shoot dry weight in both varieties ranged from 10 to $20 \%$ and did not differ with palm age. On the other hand, the ratio of pith of both varieties ranged from $15-20 \%$ to $55-60 \%$ and increased with years ATF. The pith dry weight ratio at harvesting stage was about $60 \%$ in both varieties. This value is a little higher than that in sago palms grown in Sarawak, Malaysia (Kaneko et al. 1996). Moreover, the pith dry weight ratios to the trunk dry weights at the harvesting stage in both varieties were about $80 \%$. These results compared closely with those reported by Yatsugi (1977).

\subsection{Starch Content (Percentage) in Pith of Sago Palm}

Samples were collected from the sago palm varieties Molat, Tuni, and Rotan of various ages, each growing in research gardens. The age range of Molat palms was 1-10 years ATF, 1-8 years ATF for Tuni, and 1-7 years ATF for Rotan. Samples were collected from 18 Molat palms, 17 Tuni palms, and 14 Rotan palms. Of those, five Molat, four Tuni, and five Rotan palms were at the harvesting stage, which is characterized by flower bud formation and flowering (Yamamoto et al. 2010). Total sugar and starch content in the pith were analyzed following the method of Murayama et al. (1955).

The starch percentage (dry weight basis) in the pith in Rotan increased from 1 to 3 or 4 years ATF and in Molat and Tuni from 3 to 7 or 8 years ATF. The final starch percentage (at harvesting stage) was almost the same in the three varieties (60-70\%; dry starch weight/dry pith weight $\times 100$ ). The starch percentage in the pith of each variety showed a positive and negative significant correlation with the dry matter percentage and the total sugar percentage, respectively (Yamamoto 1998, 2006; Yamamoto et al. 2010).

\subsection{Starch Yield and Its Related Factors of Sago Palm}

The starch yields of three major varieties at harvesting stage were higher, in descending order, of Molat (425 kg/palm) > Tuni $(305 \mathrm{~kg} / \mathrm{palm})>$ Rotan $(142 \mathrm{~kg} / \mathrm{palm})$ (Yamamoto et al. 2010). The starch yields of Molat and Tuni were 3.0 and 2.1 times higher than that 
Table 11.4 Starch yield and dry matter production characters related to the yield

\begin{tabular}{l|l|l|l|l|l|l|l}
\hline Variety & $\begin{array}{l}\text { Shoot wt. } \\
(\mathrm{kg} / \text { palm })(\mathrm{a})\end{array}$ & $\begin{array}{l}\text { Trunk }^{\mathrm{a}} \text { wt. } \\
(\mathrm{kg} / \mathrm{palm})(\mathrm{b})\end{array}$ & $\begin{array}{l}\text { b/a } \\
(\%)\end{array}$ & $\begin{array}{l}\text { Trunk }^{\mathrm{a}} \text { pith } \\
\text { wt. }(\mathrm{kg})(\mathrm{c})\end{array}$ & $\begin{array}{l}\text { c/a } \\
(\%)\end{array}$ & $\begin{array}{l}\text { Starch } \\
(\%)^{\mathrm{b}}\end{array}$ & $\begin{array}{l}\text { Starch yield } \\
(\mathrm{kg} / \mathrm{palm})^{\mathrm{c}}\end{array}$ \\
\hline Molat & $985.5 \pm 42.7$ & $670.4 \pm 36.2$ & 68.0 & $543.6 \pm 26.3$ & 55.2 & $68.4 \pm 4.5$ & $371.8 \pm 18.0$ \\
\hline Rotan & $363.2 \pm 82.7$ & $230.0 \pm 46.7$ & 63.3 & $185.1 \pm 41.4$ & 51.0 & $69.0 \pm 2.4$ & $127.7 \pm 28.5$ \\
\hline
\end{tabular}

${ }^{a}$ Lower trunk portion from the node of lowest living leaf, which part is actually harvested for starch extraction in sago palm-growing areas

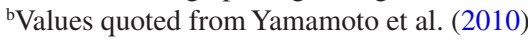

${ }^{\mathrm{c}}$ Calculated from the pith dry weight and the average starch percentage

of Rotan. Table 11.4 shows the starch yield and dry matter production characters related to the yield of both varieties. The results showed that the difference in starch yield between Molat and Rotan was based on the differences in the shoot, trunk, and pith biomasses and not on the ratios of harvested part and starch percentage in the pith.

\subsection{Conclusion}

Shoot biomass (aboveground part) of sago palm increased exponentially after trunk formation, and those at harvesting stage (flower bud formation-flowering stages) showed a greater difference between the varieties Molat and Rotan. The shoot biomass was mainly determined by the leaf area per plant, and it was primarily determined by the leaf area per leaf compared to the number of leaves. The differences in leaf area per leaf between the two varieties were closely related to the width of leaflet compared to the number of leaflet and leaflet length.

The dry weight ratio of each organ or part of sago palm shoot after trunk formation was not very different between the two varieties. The dry weight ratios of leaf and trunk to the shoot weight decreased and increased with aging, respectively, and the pith ratio of harvesting trunk was about $60 \%$.

The starch yields of Molat were three times greater than that of Rotan, and the yield differences were mainly based on the differences in shoot biomass.

The results presented above reveal that varietal differences in dry matter production based on leaf area provide useful information to establish the best methods of cultivation of sago palm and the leaf and leaflet traits may be useful as a selection trait to breed new high-yielding varieties. 


\section{References}

Flach M (1977) Yield potential of the sago palm and its realization. In: Tan K (ed) Sago '76: papers of the 1st international sago symposium: the equatorial swamp as a natural resource. University of Malaya, Kuala Lumpur, pp 157-177

Flach M, Schuiling DL (1991) Growth and yield of sago palms in relation to their nutritional needs. In: Ng TT, Tie YL, Kueh HS (eds) Towards greater advancement of the sago industry in the '90s: proceedings of the 4th international sago symposium. Kuching, Sarawak, pp 103-110

Kaneko T, Okazaki M, Kasai N et al (1996) Growth and biomass of sago palm (Metroxylon sagu) on shallow peat soils of Dalat District, Sarawak. Sago Palm 4:21-24

Miyazaki A, Yamamoto Y, Omori K et al (2007) Leaf photosynthetic rate in sago palms (Metroxylon sagu Rottb.) grown under field conditions in Indonesia. Japan J Trop Agric 51:54-58

Murayama N, Yoshino M, Oshima M et al (1955) Studies on the accumulation process of carbohydrates associated with growth of rice plant. Bull Nat Inst Agric Sci Japan Series B 4:123-166. (in Japanese)

Nakamura S, Nitta Y, Goto Y (2004) Leaf characteristics and shape of sago palm (Metroxylon sagu Rottb.) for developing a method of estimating leaf area. Plant Prod Sci 7:198-203

Nakamura S, Nitta Y, Watanabe M, Goto Y (2005) Analysis of leaflet shape and area for improvement of leaf area estimation method for sago palm (Metroxylon sagu Rottb.) Plant Prod Sci $8: 27-31$

Nakamura S, Nitta Y, Watanabe M, Goto Y (2009) A method for estimating sago palm (Metroxylon sagu Rottb.) leaf area after trunk formation. Plant Prod Sci 12:58-62

Nitta Y, Matsuda T, Miura R et al (2005) Anatomical leaf structure related to photosynthetic and conductive activities of sago palm. In: Karafir YP, Jong FS, Fere VE (eds) Sago palm development and utilization: proceedings of the 8th international sago symposium. Universitas Negeri Papua Press, Manokwari, pp 105-112

Omori K, Yamamoto Y, Nitta Y et al (1999) Differences of stomatal density by palm ages and varieties in sago palm (Metroxylon sagu Rottb.). In: Proceeding of the 8th conference of the society of sago palm studies, pp 10-15 (in Japanese)

Omori K, Yamamoto Y, Nitta Y et al (2000) Stomatal density of sago palm (Metroxylon sagu Rottb.) with special reference to positional differences in leaflets and leaves, and change by palm age. Sago Palm 8:2-8

Uchida N, Kobayashi S, Yasuda T, Yamaguchi T (1990) Photosynthetic characteristics of sago palm, Metroxylon rumphii Martius. Japan J Trop Agric 34:176-180

Yamamoto Y (1998) Sago palm. Tropical agriculture series, tropical crop manual No. 25, Association for International Cooperation of Agriculture and Forestry, Tokyo (in Japanese)

Yamamoto Y (2006) Starch productivity of sago palm (Metroxylon sagu Rottb.) in Indonesia and Malaysia. Japan J Trop Agric 50:234-237. (in Japanese)

Yamamoto Y (2011) Starch productivity of sago palm and the related factors. In: Siregar IS, Sudaryanto T, Ehara $\mathrm{H}$ et al (eds) Sago for food security, bio-energy, and industry, from research to market: Proceeding of the 10th international sago symposium, Bogor, pp 9-15

Yamamoto Y (2016) Matter production as a basis of starch production in sago palm (Metroxylon sagu Rottb.). In: Ehara H, Toyoda Y, Mishima T et al (eds) Proceeding of the 12th international sago symposium, Tokyo, pp 1-5

Yamamoto Y, Katayama K, Yoshida T et al (2006) Changes of leaf characters with ages in two sago palm varieties grown near Jayapura, Papua state, Indonesia. In: Proceedings of the 15 th conference of the society of sago palm studies, pp 1-4 (in Japanese)

Yamamoto Y, Rembon FS, Omori K et al (2010) Growth characteristics and starch productivity of three varieties of sago palm (Metroxylon sagu Rottb.) in Southeast Sulawesi, Indonesia. Trop Agric Devel 54:1-8

Yamamoto Y, Omori K, Nitta Y et al (2014) Changes of leaf characters in sago palm (Metroxylon sagu Rottb.) after trunk formation. Trop Agric Devel 58:43-50 
Yamamoto Y, Omori K, Nitta T et al (2016) Dry matter production and distribution after trunk formation in sago palm (Metroxylon sagu Rottb.) Trop Agric Devel 60:71-80

Yatsugi T (1977) Sago starch. In: Nakamura M, Suzuki S (eds) Starch science handbook. Asakura Shoten, Tokyo, pp 404-410. (in Japanese)

Yoshida T, Omori K, Yamamoto Y et al (2000) Mineral contents in leaf and pith of three varieties grown in Kendari, Southeast Sulawesi, Indonesia. In: Proceeding of the 9th conference of the society of sago palm studies, pp 23-30 (in Japanese)

Open Access This chapter is licensed under the terms of the Creative Commons Attribution 4.0 International License (http://creativecommons.org/licenses/by/4.0/), which permits use, sharing, adaptation, distribution and reproduction in any medium or format, as long as you give appropriate credit to the original author(s) and the source, provide a link to the Creative Commons license and indicate if changes were made.

The images or other third party material in this chapter are included in the chapter's Creative Commons license, unless indicated otherwise in a credit line to the material. If material is not included in the chapter's Creative Commons license and your intended use is not permitted by statutory regulation or exceeds the permitted use, you will need to obtain permission directly from the copyright holder. 